RAKSTI - ARTICLES

\title{
NEPAMET MUMS GRĒKUS MŪSU JEB LATVIEŠU TĖVREIZE 16. GS. PASAULES APRAKSTOS UN TÉVREIŽU KRĀJUMOS
}

\author{
Ernesta KAZAKĖNAITÉ \\ Viḷ,nas Universitāte
}

\section{Ievads}

Tēvreize ir svarīgākā lūgšana, ko katrs kristietis atceras no galvas. Iespējams, tas ir viens no iemesliem, kāpēc 16.-18. gs. tēvreizes bija populārs valodu paraugs vai to salīdzināšanas veids. Tā 1550. g. publicēts senākais zināmais iespiestais teksts latviešu valodā - tā saucamā Hāzentētera tēvreize, atrodama Sebastiāna Minstera kosmogrāfijā. ${ }^{1}$ Arī vecākais latvisks saistīta teksta fragments rokrakstā ir minētā lūgšana. Tādējādi tēvreizes kā pirmie teksti latviešu valodā vienmēr bijušas pētnieku redzeslokā un daudz analizētas dažādos veidos, piem., publicēti jauni atrasti lūgšanas rokraksti (Bezzenberger 1875: 45-60; Biezais 1955; 1957), kas vēlāk precizēti (Draviņš 1955), apspriestas drukātās tēvreizes (Meringer 1895; Arbuzovs 1920; Augstkalns 1930 utt.), pievēršot uzmanību to valodai (Pokrotniece 2012) vai skatot baltu valodu izpratnes kontekstā (Dini 2010). Gan pirmajām ar roku rakstītajām, gan drukātajām tēvreizēm neapšaubāmi ir liela loma latviešu rakstu valodas izpētē. Tomēr turpmāk rakstā analizētie publicējumi visbiežāk ir pārspiedumi, kuriem raksturīgas kḷūias, kas, iespējams, pārmantotas no viena avota citā un kas, jāteic, izskatās pēc Hāzentētera tēvreizes klusajiem telefoniem.

Šis raksts savā ziņā ir pētījuma par Hāzentētera latviešu tēvreizes S. Minstera kosmogrāfijās (Kazakẻnaitė 2020) turpinājums, taču tā mērkis ir sniegt nelielu ieskatu par tēvreizes publicējumiem citos pieejamajos 16. gs. pasaules aprakstos un tēvreižu krājumos, uzmanību pievēršot tekstu sakariem. ${ }^{2}$ Rakstā pārskatìti astoņi latviešu tēvreizes publicējumi, kas atrodami līdz 1600. g. izdotajos avotos, t. i.: Lācija aprakstos, Belsku hronikās, Tevē

Münster, Sebastian 1550. Cosmographei || oder beschreibung aller lån/|| der/ herschafften/ fürnemsten || stetten/ geschichten/ gebreūchē/ hantierungen etc. [...]. Basel: Petri. Plašāk sk. Draviņš 1952.

2 Kaut raksta tēma radās nejauši, cenšoties noskaidrot evangêelisko tekstu vēsturi, tas nav nedz pirmais (sk. Arbuzovs 1920; Zēvers 1929; Augstkalns 1930; Dravinš̌ 1965; Hinze 1976; Dini 2010 utt.), nedz laikam pēdējais šāds mēǵinājums, jo jauni avoti rodas nepārtraukti. 
kosmogrāfijā un Megisera tēvreižu krājumos. Visi autori latviešu veco tekstu pētniekiem ir zināmi, tomēr pēc Minstera kosmogrāfijā (turpmāk - MK) esošās tēvreizes analīzes dažādas detaḷas ir precizējamas, kā arī jārunā par diviem Megisera 1593. g. publicējumiem, nevis vienu.

Minētie izdevumi raksta turpinājumā tiek apskatīti atsevišksi: vispirms pasaules apraksti (2.), tad tēvreižu krājumi (3.). Pēdējā raksta dạ̣ā (4.) aplūkoti teksta atkalizmantošanas virzieni un sniegta sakaru shēma, kurā visi pētāmie publicējumi, iekḷaujot arī agrākā pētījuma secinājumus par Minstera kosmogrāfiju, apkopoti hronolog̣iskā secībā. Pielikumā atrodams paralēlais tēvreižu korpuss.

\section{Latviešu tēvreize 16. gs. pasaules aprakstos}

Lai gan 16. gs. pasaules apraksti tiek skaitīti desmitos, tikai dạ̦ā atrodams kāds Livonijas apraksts, kam pievienots tajā runātās valodas paraugs. Līdztekus populārajai Minstera kosmogrāfijai latviešu tēvreize 16. gs. pasaules aprakstu izdevumos meklējama vēl Volfganga Lācija (2.1.), Marcina un Joahima Belsku (2.2.) un Andrē Tevē (2.3.) darbos.

\subsection{Tēvreize V. Lācija darbos}

Otrais autors pēc Minstera, kas savā darbā iekḷāvis latviešu tēvreizi, ir Volfgangs Lācijs. ${ }^{3}$ Interesantā kārtā grāmatā De gentium aliquot migrationibus .. (1557) sniegto tekstu viņš nav identificējis kā latviešu valodas paraugu, bet nosaucis to par heruḷu („Herulorum“) jeb veruḷu („Vuerulorum“) valodu. Par šādu lēmumu vēlāk ticis daudz rakstīts (Schirren 1858; Döring 1883; Meringer 1895 utt.), taču îstie iemesli nav zināmi ${ }^{4}$, tomēr nav šaubu, ka Lācija grāmatai bijusi liela ietekme uz citiem darbiem, jo kopš tā laika vēl ilgi tēvreižu krājumos klaiņoja šis „,heruḷu“" valodas paraugs, kas atrodams 17. gs., 18. gs. un vēl pat 19. gs. sākuma krājumos. ${ }^{5}$

3 Vācu Wolfgang Laz, lat. Lazius (1514-1565), slavens Austrijas kartogrāfs, Vīnes Universitātes medicīnas profesors (vairāk sk. Svatek 2006).

4 Ir dažādi minējumi, piem., ka Lācijs saņēmis kādu rokrakstu vai MK esošās tēvreizes norakstu bez nosauktās valodas, taču tas ir apšaubāms, jo diez vai Lācijs nebūtu zinājis šo slaveno izdevumu (viņam bijuši sakari ar Bāzeles intelektuāliem (Jurkiewicz 2009: 111)), un teksts acīmredzami ņemts no MK ar interlineāro tulkojumu, kurā skaidri rakstīts, ka tā ir Livonijā runātās valodas paraugs.

5 Piem., 1679. g. Jana Kšištofa Hartknoha (Jan Krzysztof Hartknoch) Selectae Dissertationes Historicae De Variis Rebus Prussicis (88. lpp.); 1715. g. Džona Čemberlena (John Chamberlayne) Oratio dominica in diversas omnium fere gentium linguas versa (87. lpp.); 1806. g. Oratio dominica in CLV linguas versa et exoticis characteribus plerumque expressa (tēvreize ar nr. CLXXXVII) utt. 
Škiet, ka Lācijs De gentium aliquot migrationibus gatavojis ilgi - pieminējis jau 1551. g. (Mayr 1894: 10), ievads un pēcvārds parakstīti ar 1555. g., tomēr grāmata izdota tikai 1557. g. Tās pēcvārdā autors min izdevuma kḷūàs un sola tās labot nākamajā izdevumā. Taču nākamais, t. i., otrais, dienas gaismu ieraudzīja jau pēc viņa nāves - 1572. g. - , bet trešais - 1600. g. Abi pirmie izdoti Johannesa Oporina tipogrāfijā Bāzelē, bet pēdējais iznācis Frankfurtē, Andrēasa Vēhelusa (Andreas Wechelus) mantinieku tipogrāfijā. Latviešu tēvreize atrodama visos.

No daudziem pārējiem 16. gs. latviešu tēvreizes publicējumiem Lācija grāmatā sniegtā atšksiras vispirms formāli - visos izdevumos rakstīta lielajiem burtiem, un rindstarpā virs vārdiem nav pievienots burtisks tulkojums citā valodā (sal. 1. attēlu). Lūgšanas teksts pirmajā un otrajā izdevumā ir vienāds (sal. 1. un 2. tēvreizi pielikumā), taču jaunā salikuma dēḷ (1557. g. izdevumā tēvreize aizņem septiņas rindiņas, bet 1572. g. salikumā, līdzīgi kā vēlākajā, sešas) atškiriras vārdu pārnešana jaunā rindā. ${ }^{6}$ Trešajā Lācija grāmatas izdevumā latviešu tēvreize no iepriekšējām atšksiras, taču tikai ar trim iezīmēm ${ }^{7}$ (sal. 1., 2. un 3. tēvreizi pielikumā): vvaarcz $\rightarrow$ vvaartcz, praatz $\rightarrow$ praats un pammate mons $\rightarrow$ pammatemvns. Atšksirības liekas sīkas un varēja rasties iespiešanas procesā - trešais izdevums gatavots jau citā tipogrāfijā, un neapšaubāmi tā teksts likts no jauna. Lai gan tas palielina iespēju rasties jaunām korektūras ķ̣ūdām, pirmie divi izmaiņu piemēri tomēr raisa kādas aizdomas par apzināti veiktām izmain̄ām, jo vvaarcz $\rightarrow$ vvaartcz piemērā $t$ burts pielikts klāt vietā, kurā visos pārējos 16. gs. avotos tas ir atrodams (izņemot vienīgo J. Belska publicējumu 1597. g., kurā ir waarc), bet praats ar s vārda beigās rakstīts gandrīz pusē visu publicējumu: 1550.-1564. un 1588.-1592. g. MK vācu valodā, arī visos MK latīnu un itāḷu izdevumos (sal. 16. vārdu pielikumā, arī Kazakėnaitė 2020: 82). Tātad izmaiņas nav nevietā, tomēr apgalvot, ka, gatavojot šo izdevumu, veikts salīdzinājums ar MK vācu vai latīṇu valodā, ir pārāk grūti. Pirmkārt, tāpēc, ka šì tēvreize esot heruḷu valodā un pirmavots, ar kuru būtu jāsalīdzina, nav norādīts. Otrkārt, ja teksts būtu konsekventi salīdzināts ar minētajām tēvreizēm, būtu jābūt vairāk izmaiņām, kā arī varbūt būtu laboti vārdi, kas atrodas paskaidrojumā zem tēvreizes (pašlaik atstāts kā pirmajā publicējumā).

6 Jāpiebilst, ka divu vārdu rakstības neskaidrības dēẹ (kopā vai škirti pammate muns) būtu iespējams saskatīt atškkirību. Šeit uzskatīts, ka vārdi 1557. g. izdevumā rakstāmi škirti (tāpat Lautenbahs 1928: 105), bet Meringera (1895: 490-491) transkripcijā - kopā.

7 Meringers (1895: 490) identificējis vienu - praats. 
ex cômercio afuéfcebant, fuo idiomati inferuiffe. Quemadmodü lingua pofte, ritatis Herulorü argumento eft, quę noftra çtate natale folü tenet in Meclabur genfi ditione, nomine Vuerulorú. Placet Dominicã orationem eius gentis re cenfere, in qua alix funt uoces Latina corrupta, alix originis Teutonicx:

TABES NVS KAS TV ES ECKSCHAN DEBBESSIS SCHVVE, TITZ TOVVS VVAARCZ ENAK MVMS TOVVS VVALSTIBE TOVVS PRAATZ BVSKA ECKSCHAN DEBBES TA VVVRSAN SVMMES MVSSE DENISCHE MAYSE DVTH MVMS SCHODEN P IMMATEMVMS MVSSE GRAKE KA MESSPAMMATMVS, $\mathrm{VU} \quad 3 \quad S E$

788 DE HERULIS, RUGIS,O6.

SE PATRA DVEKEN, NE VVEDDEMVMS LOVNA BADE, C CKLE, PETT PASSARZA MVMS NV VVVSSELOVNE,Amen. In qua primum uocabulü patris gentilitium eft.qua fequũtur, Latinafunt qua tuor deprauata: Neurs, qui,tu,es. Corruperãt fortè dũ in Latio colebãt, aut Ro manis in caftris militarêr, Mus ka tu es. Sextũ \& feptimũ rurfus gentilitiafunt, et barbara, Eckfehan pro in, et Debefsis pro cœlos.ueluti et octauũ Sd)we, riţ, quod fignificat Sanctificetur. Tows nonü, rurfus Latinü eft corruptum, pro tuũ. Decimum \& undecimũ gẽtrilitialunt, Vuaarcz pro nomine, \& Enak pro adueniat.Duodecimum Germanicứ corruptū eft, Moms pro uns, una lite ra adiecta. Vualftibe proregno, \& praacz pro uoluntate, gentilitia forté Teu tonica originalis.nam qua hodie uoce Voluntate appellamus, \& regnum, wif len,wellet, tetch, Latina funt, \& à Romanis noftre lingux inferta. Rurfus deci maqnta uox, Tows Romanú eft deprauatũ. Quxfequunt́, barbara funt: Bus; Ekfcham, Debbes, id eft, ficut in coelo: wourfanfumes, id eft, ita in terra. Quo rũ Debbes latinũ de prauatũ effe autumo, à Deo,cũ barbari caelũ nô poflent ni fi a Deonominare. Arbitror \& poftrema Teutonica effenam $\&$ hodie Sumpf terram paluftrë dicimus: \& quãdo aliquid ex uolütatefuturum proferre uolu, mus, dicere folemus, ut Romani folent, Fiat, \& Hebrai Amen, nos wow de, es woet sronunciamus. Ex fequentib.fi côiecture eft aliquid tribuendü, et Dent

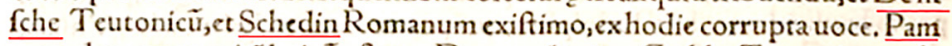
mate deprauatum itẽ latinú eft, pro Donate, dimitte. Grakhe Teutonicum eft; nam et maiores noftriultionem debitam Racham dixere: ita Paraducken in il lo idiomate debitores fignas: \& Louna, quod eft nimirum corruptum Germanicü, malư demôftrat. Hinc hodie adhuc dicimus, sin bof fentsumets, id eft, malrm famã. \& Auftriaci nos ac Styri trifte àmalis uexatư, launig appellamus. D

1. attēls. Latviešu tēvreize V. Lācija De gentium aliquot migrationibus (1557), 787.-788. 1 pp. ${ }^{8}$

Vēl dažviet tiek minēts, ka nav zināms, no kurienes tieši Lācijs ir ņēmis latvisko tekstu (Jurkiewicz 2009: 110), tomēr jau kopš 20. gs. sākuma latviešu darbos lasāms, ka šì tēvreize ir „Hazentoetera-Muenstera tēvreiz[e]

8 Bavārijas Valsts bibliotēkas eksemplārs, sign. ESlg/2 H.int. 67. 
ar Lacija paviršām kḷūdām“ (Arbuzovs 1920: 360; līdzīgi Prande 1926: 13) vai pat „Lācija plaǵiāts“ no Minstera (Augstkalns 1930: 310). Patiesībā tas paman̄its daudz agrāk, piem., Johana Kristofa Adelunga grāmatā (1806: 688), bet pamatots Kārḷa Širrena darbā (Schirren 1858; pārdrukāts arī 1859). ${ }^{9}$ Širrens ir pierādīịis, ka tēvreizes pamatā bijis interlineārais teksts no Minstera kosmogrāfijas vācu izdevuma, lai gan norakstìts ar daudzām neprecizitātēm. Tam ne tikai jāpiekrīt, bet iespējams papildināt, ka no tēvreizēm MK latīṇu un franču izdevumos šì noteikti atšksiras, jo nav atkārtotas to tipiskās iezīmes, kā ne euuedde, mus tabes u. c. (sk. Kazakènaitė 2020). No vācu 1550. g. un identa 1553. g. pieraksta Lācija publicējumi atškisiras ar rakstību — viss teksts lielajiem burtiem, $u$ vietā $v, w$ vietā $v v$ utt.; arī: waartz $\rightarrow$ vvaarcz, bus $k a \rightarrow$ bvska, fchodeen $\rightarrow$ schoden, Ne wedde mums $\rightarrow$ Ne vveddemvms, paffarga $\rightarrow$ passarza, eckfchkan $\rightarrow$ eckschan, femmes $\rightarrow$ summes, parradueken $\rightarrow$ patra dveken. Vairākums izmaiņu, š̉iet, ir korektūrā, taču pēdējie trīs piemēri šai ziṇā atškịiras vairāk, lai gan arī tās būtu uzskatāmas par korekcijām, kas radušās pārrakstīšanas vai iespiešanas procesā. Taču nekas lielāks par minētajām izmainaām nav atrodams - atkārtoti visi tie paši vārdi tajās pašās pozīcijās.

Par Lācija kā tā laika autora nevērīgumu ieminējušies teju visi viņa darbu pētnieki. ${ }^{10}$ To rāda ne vien tîšām vai netīšām kḷūdaini nosauktā tēvreizes valoda, bet arī tas, ka tie paši vārdi vienā rindkopā rakstīti atšksirīgi. Te jāakcentē, ka Lācijs ne tikai sniedz latviešu tēvreizi, bet arī, salīdzinot ar latīṇu un vācu valodu, zem teksta atkārto vairāk nekā pusi tās vārdu (tālāk nosaukto vārdu dalias treknrakstā rāda atškịirības no sniegtā tēvreizes teksta; sal. arī ar 1. attēlu) ${ }^{11}$, t. i.: Mus ka tu es, Eckfchan, Debefsis, Schweritz, Tows, Vuaarcz, Enak, Moms ${ }^{12}$, Vualstibe, praacz, Tows, Bus, Ekfcham, Debbes, wurfan fumes, Debbes, De nifche, Schedin, Pammate, Grakhe, Paraducken, Louna. ${ }^{13}$ Lielāko daļu vārdu rakstot ar mazajiem latīṇu burtiem (daži sniegti gotiskajā rakstībā), Lācijs vietām diezgan konsekventi $v$ nomainīịs ar $u, v v-$ ar $w$, $s-\operatorname{ar} f$, tomēr citas īpatnības rāda neprecizitāšu daudzumu, kā arī sakaru ar vācisko MK izdevumu un liek domāt, ka precīza to atveidošana nebija autora

9 Balstoties uz Ozolu (1965: 58), šis pētīiums neesot bijis pamanīts.

${ }_{10}$ Par kritiku Lācija darbiem sk. Kratochwill 1965; Kössinger 2015: 32.

11 Teksta transkripcija atrodama vēl Meringera (1895: 491) rakstā, tomēr tajā ir palikušas dažas korektūras kḷūdas, viena no tām ir latviskajā vārdā panimate, kas oriğinālā ir pammate. Cita transkripcija ir Brežgo (1939: 1024) Livonijas apraksta analīzē.

12 Jāteic - lai gan moms tēvreizēs atrodams vienīgi latīṇu izdevumos, šeit MK latīṇu valodā ietekme nav saskatāma, jo to neatbalsta citas latīṇu variantam raksturīgās pazīmes (sal. Kazakènaitė 2020).

${ }^{13}$ Vēlākajos izdevumos ir dažas ar salikumu saistītas atškirīības (pārnešana citā rindā, virgulēts patskanis utt.). 
mērksis. Tomēr laikabiedri Lāciju laikam uzskatījuši par autoritatīvu autoru, jo, kā norādīts iepriekš, uz viṇu balstījušies vēl daudzi un ilgi.

\subsection{Tēvreize Belsku hronikās}

\subsubsection{Tēvreize Marcina Belska hronikā}

Marcina Belska ${ }^{14}$ visas pasaules hronika - Kronika wszystkiego świata viņa dzīves laikā izdota trīs reizes Krakovā: 1551. g., 1554. g. un 1564. g. Pēdējā, papildinātajā izdevumā atrodama arī latviešu tēvreize, kas vārds pa vārdam izanalizēta jau 19. gs. pētnieku darbos (sk. Meringer 1895). Tā nav tipiska citos avotos atrodamajai, jo tās pamatā, liekas, ir poḷu tēvreize, kam mazākā drukā sniegts tulkojums latviešu valodā, bet iepriekšējos avotos, kuros blakus atrodams tulkojums, ir pretēji - latviešu tēvreizei dots starprindu tulkojums citā valodā.

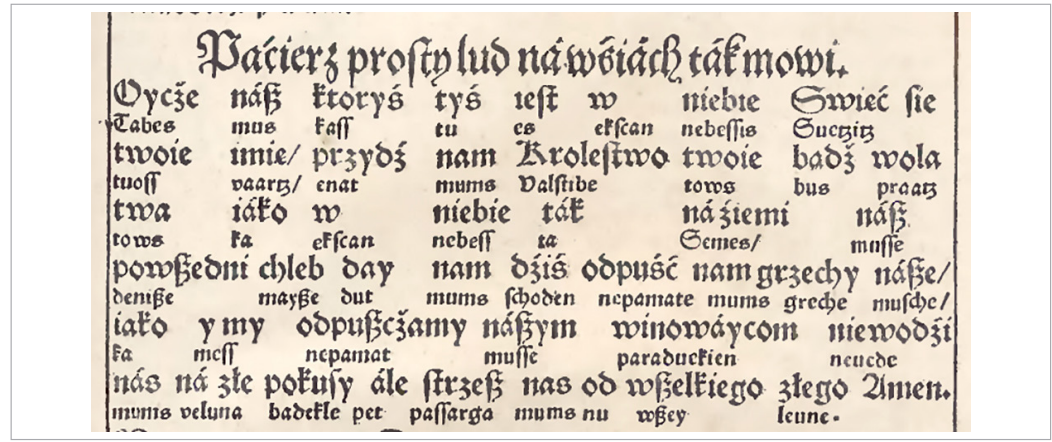

2. attēls. Latviešu tēvreize M. Belska Kronika wszystkiego świata (1564), 438. lpp..$^{15}$

Šķiet, lai gan latviešu tēvreize vārdu secībā pielāgota poḷu lūgšanai, autors latviešu valodu nav pratis. Kā secinājuši arī agrākie pētnieki (Meringer 1895: 495; Zēvers 1929: 513; Augstkalns 1930: 310), var redzēt, ka viņš balstīiies uz Minstera kosmogrāfijā sniegto paraugu un vācu burtisko tulkojumu, kaut atšksirību ir daudz un ne vien rakstībā. To lielā skaita dēl nav iespējams precīzi noteikt, kurš no Minstera vācu kosmogrāfijas izdevumiem izmantots hronikā.

14 Marcins Belskis (Marcin Bielski) dzimis ap 1495. g., miris 1575. g. Belā (vairāk sk. Chrzanowski 1926).

${ }_{15}$ Nacionālā Osoliņska institūta eksemplārs, sign.: XVI.F.4111. Brīvpieeja: Lejassilēzijas bibliotēkas digitālā kolekcija (Dolnośląska Biblioteka Cyfrowa kolekcja). 
Atliek tikai minēt, ka vārda muffe rakstīšana savienojumā muffe paraduekien varētu rādīt, ka izmantots 1558. g. vai vēlāks izdevums, jo agrākajos atrodams $m u ß e$, kam citviet Belska variantā atbilst mufche. Tomēr, ņemot vērā haotisko M. Belska rakstību tēvreizēe, šis minējums var būt tikpat patiess, cik kḷūuains, tāpēc tālāk sakaru shēmā (sk. raksta beigās) kā iespējams avots norādīti visi pirms hronikas izdotie Minstera vācu kosmogrāfijas publicējumi.

Kā redzams 2. attēlā, dažu vārdu latviešu tēvreizē iztrūkst un daži ir „pārpoloti““, piem., ná źiemi ekvivalents ir tikai Semes (virs ir pazudis), debess vietā nebess (poḷu niebo), vēl rakstīts wßey (poḷu wßelkiego) vai greche (poḷu grzechy). Vienu reizi lạns vietā radies veluna, tomēr tai pašā rindiņā otrs atstāts, rakstot leune. Rūdolfs Meringers (1895: 498) domā, ka M. Belskis sev nezināmā vārdā saskatīịis lietuviešu velinas 'velns' ( $i$ vietā $u$ esot drukas kḷūda), ko tai pašā lappusē zemāk ir divreiz pieminējis. ${ }^{16}$ Taču, pat ja tā ir patiesība, paliek neskaidrs, kāpēc tam pašam vārdam sniegti divi varianti. Viens no iemesliem var būt grafiska līdzība - sniegtajai lietuviešu vārda formai veluna līdzīgāks leuna, nevis leune.

No citiem 16. gs. tēvreizes pierakstiem visvairāk atšksirīgā šĩs tēvreizes īpatnība ir piektajā lūgšanā pamet vietā divreiz lietotais nepamet, t. i., nepamate mums greche mufche / ka meff nepamat muffe paraduekien (ekvivalents mūsdienu lasījumā būtu nepiedod mums mūsu parādus, kā arī mēs nepiedodam saviem parādniekiem). Tomēr, ņemot vērā visas tēvreizes īpatnības, diez vai š̀̃, pēc pirmā acu uzmetiena drošā, izmaiņa lūgšanā bijusi mērkstiecīga. Kā jau aizrādījis Meringers (1895: 498), vārds var būt ticis saistīts ar autoram labi zināmo poḷu pamiętać 'atcerēties' vai kādu citu vārdu, kam pēc nozīmes pievienota negācija. Šis latviešu tēvreizes paveids savā ziņā ir perfekts laikmeta, kad precizitāte uztverta citādi, atspulgs.

\subsubsection{Tēvreize Joahima Belska pilnveidotā hronikā}

Līdz pat dzīves beigām 1575. g. M. Belskis esot turpinājis darbu pie hronikas pilnveidošanas, aprakstīdams jaunus notikumus, taču viss palicis rokrakstā (Chrzanowski 1926: 29). Toties viņa darbu turpināja dēls Joahims ${ }^{17}$, kurš 1597. g. vēsturiskiem notikumiem papildinātu hroniku izdevis ar nosaukumu Kronika polska Marcina Bielskiego nowo przez Ioach. Bielskiego syna iego wydana [..]. ${ }^{18}$ Kaut š̄ grāmata bibliogrāfijās atrodama

\footnotetext{
${ }_{16}$ Belskis 438. lpp. raksta: „Ifgaleta Jauesti Kitristas velino/ Kuri faua futrine Lampfe velina.“

17 Poḷu Joachim Bielski (ap 1540-1599), vairāk sk. Barycz 1936: 61-64.

18 Jāpiebilst, ka vēlākie pētnieki biežāk citē šs̄s grāmatas atkārtotu izdevumu, ko 1856. g. izdeva Turovskis (Turowski). Tās otrā sējuma 1129. lpp. atrodamajā latviešu tēvreizes transkripcijā atstātas kḷūàas, piem., swecic vietā swocic utt.
} 
ar M. Belska vārdu, Hšanovskis (Chrzanowski 1926: 128) to uzskata par atsevišksu darbu, jo tā ne vien papildināta, bet arī pārveidota, tomēr latviešu tēvreizi atkārtojot ${ }^{19}$.

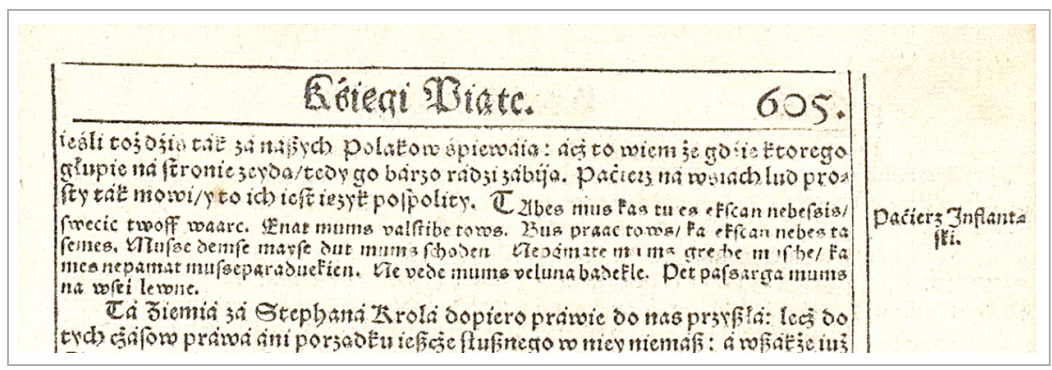

3. attēls. Latviešu tēvreize J. Belska Kronika polska (1597), 605. 1pp. ${ }^{20}$

Salīdzinot 2. un 3. attēlu, redzams, ka tēvreizes atškiras ne tikai ar pasniegšanas veidu (bez interlineāra tulkojuma utt.), bet arī rakstību. Zinot, ka M. Belska dēls, gatavojot hroniku, dažreiz skatīies avotos (Chrzanowski 1926: 29), varētu gaidīt arī kādas izmaiņas latviešu tēvreizē. Kaut korekcijas vērojamas, tās acīmredzami veiktas ne cita avota ietekmē, bet rediḡejjot vai pārrakstot to pašu tēvreizi. Dažas izmaiņas škiet gana konsekventas, piem., $t z$ vietā $c$ (vaartz $\rightarrow$ waarc, praat $z \rightarrow$ praac), $\beta$ vietā $f($ deni $\beta e ~ \rightarrow \operatorname{demfe}$, may $\beta e \rightarrow$ mayfe, wßey $\rightarrow$ wfei) vai, visbiežāk, vārda vidū esošo ff vietā $f_{s}$ (nebeffis $\rightarrow$ nebefsis, muffe $\rightarrow$ Mufse, paffarga $\rightarrow$ pafsarga $)$, bet vārda beigāsff vietā s (kaff $\rightarrow$ kas, nebeff $\rightarrow$ nebes, meff $\rightarrow$ mes); dažviet $u$ vietā atrodams $w$ (Suetzitz $\rightarrow$ fwecic, tuoff $\rightarrow$ twoff, leune $\rightarrow$ lewne). Divreiz atšksiras vārdu rakstīšana kopā vai škirti - muffe paraduekien neuede $\rightarrow$ mufseparaduekien. Ne vede. Laikam arī šajā publicējumā redzama tǐša vai netīša vārdu „pārpoḷošana“ - vienreiz $n u$ vietā ir $n a$. Vēl dažviet atškiras interpunkcija un lielo burtu lietojums (sal. 4. un 5. pierakstu pielikumā). Tātad izmainu ir visai daudz, bet, vai tās ir veicis vēl $\mathrm{M}$. Belskis savā rokrakstā vai jau J. Belskis, grūti atbildēt. Tomēr šksiet, ka J. Belska sniegtā latviešu tēvreize nav norakstīta tieši no M. Belska 1564. g. drukātā izdevuma, bet no kāda rokraksta, jo atšksiras ne tikai rakstība, bet arī vārdu un teikumu dalījums.

19 Šīs tēvreizes transkripciju ir sniedzis Zēvers (1929: 514), tomēr tā atškiras no šai rakstā sniegtās (sal. ar 3. attēlu), piem., te ceturtajā lūgšanā ir mums, bet Zēveram - mum, Nepamate - Nepomate, na - no.

${ }^{20}$ Jagelonu Universitātes bibliotēkas eksemplārs, sign. BJ St. Dr. Cim. 8691. Brīvpieeja: polona.pl. 
Apkopojot teikto par abām Belsku tēvreizēm, jāsecina, ka šī ir visatš̌sirīgākā pašlaik zināmā iespiestā 16. gs. latviešu tēvreize, tomēr, kaut dažviet grūti pamatot korekciju izcelsmi, tai pamatā bijusi tā pati Hāzentētera tēvreize, kas atrodama MK.

\subsection{Tēvreize A. Tevē kosmogrāfijā}

Līdztekus 1575. g. izdotajai pēdējai Minstera kosmogrāfijai franču valodā tikai pāris mēnešu vēlāk Parīzē izdots arī Francijas karaḷa oficiālā kosmogrāfa Andrē Teve ${ }^{21}$ pasaules apraksts divos sējumos La cosmographie universelle .. . Lai gan šī grāmata publicēta mazliet vēlāk, domājams, tieši tās vairākus gadus ilgusī gatavošana, nevis otrādi, ierosinājusi pēdējo Minstera franču kosmogrāfijas izdevumu, kura jauno, krietni papildināto tulkojumu veicis bijušais Tevē draugs Fransuā de Belforē (François de Belleforest; Dickason 1992: 1).22 Ar pilnveidotu kosmogrāfijas izdevumu franču valodā de Belforē gribējis sniegt savu skatīijumu uz pasauli, uzskatīdams, ka Tevē grāmata būs pilna ar maldīgām zin̄ām. Lai arī Tevē bija pat četru Francijas karalıu kosmogrāfs, laikabiedri par viņa darbiem izteikušies l̦oti kritiski (Schlesinger, Stabler 1986: xxii, xxxiii). ${ }^{23}$

\section{En Liuonien.}

1 Vs tabes kas tw es, ecksckan debbeßis, fchunetitz tous wuadrz, Enack mums towis duth mums chodeen, pammate mums muffe grake ka meß pammart mufje parradueken. Ne cuuedde mums iouna badeckle peti, paffarga mums nu vunffe ionne. Amen.

4. attēls. Latviešu tēvreize A. Tevē La cosmographie universelle .. (1575), 882. 1 pp. ${ }^{24}$

${ }^{21}$ Biogrāfiskie dati nav skaidri, literatūrā atrodams 1502., 1504., 1516. vai pat 1517. dzimšanas gads un 1590. vai 1592. miršanas gads (sk. plašāk da Silveira Cardozo 1944: 24-25 vai Schlesinger, Stabler 1986: xix).

22 Te būtu jāmin, ka A. Tevē un F. de Belforē draudzību un sadarbību pārtraukuši strīdi par plag̣iātu (da Silveira Cardozo 1944: 26).

23 Īpaši kritizēts Tevē apraksts par Kanādu, kurā viņš esot bijis. Sākumā grāmatā Singvlaritez (1557) rakstīiis, ka bijis ḷoti tuvu tai, bet pēc vairāk nekā desmit gadiem kosmogrāfijā apgalvojis, ka toreiz tur izcēlies un pavadījis 20 dienas, pat runājis ar vietējiem (Schlesinger, Stabler 1986: xxii).

${ }^{24}$ Francijas Nacionālās bibliotēkas eks., sign. FOL-SG BON B-2. Brīvpieeja: Gallica katalogā. 
To, ka A. Tevē kosmogrāfija otrajā sējumā satur ne vien Livonijas aprakstu, bet arī valodas paraugu, pamanīịis jau Pēteris Sēja (1925)25. Savā īsajā ziņojumā viņšn nav nosaucis iespējamo avotu, tomēr Izglìtības Ministrijas Mēnešraksta redakcijas piezīmē zem ziņojuma skaidri rakstīts, ka tas ir 1550. g. Hāzentētera tēvreizes variants (Sēja 1925: 285). Precizējot, tas ir franciskās MK tēvreizes paveids, jo tajā atrodama tipiskā lūgšanas uzruna MVs tabes, kā arī vārdu salikumi eka kfchkan, pammart un iouna. Tomēr Tevē tēvreize rakstības ziṇā atškiras no visām iepriekš minētajām, piem., tikai šajā rakstīts debbeßis, vuaartz, iouna, vuuffe, un noteikt, kurš tieši MK franču izdevums ir izmantots, nav viegli. Tevē tēvreize visvairāk atškiras no pirmā (1552. g.) izdevuma, mazāk no otrā un trešā, tomēr apgalvot, ka tā sakrīt vienīgi ar 1565.-1568. g. izdevumu, arī grūti. Nenoliedzamas sakritības rāda, ka Tevē tēvreizes pamats tiešām varēja būt 1565. g. vai identa 1568. g. MK (atkārtotas tikai šajos izdevumos pirmo reizi vērojamas īpatnības, kā eka kfchkan un pammart), taču dažu vārdu rakstība mudina domāt, ka teksts salīdzināts ar agrāko 1560. g. MK franču izdevumu. Tevē tēvreizē tāpat kā 1560. g. MK rakstīts parradueken, vurfan, vualstibe, touus, lai gan 1565.-1568. g. izdevumos ir parraducken, uurfan, uualstibe, tous. Grūti atbildēt, vai šo vārdu vienādā rakstǐšana ir nejauša sakritība (izvēloties līdzīgu pan̄ēmienu), jo tas nav viens individuāls gadījums, tomēr apgalvojums, ka Tevē tekstu rediǵêja pēc 1560. g. MK, lai gan par pamatu ņēma vēlāko, izraisa vēl vairāk neatbildamu jautājumu, piem., kāpēc korig̣ēti tikai šie vārdi.

Latviešu tēvreizes pierakstam Tevē pasaules aprakstā bija liela nozīme, jo tā iemantoja popularitāti un loti ietekmēja arī vēlākos frankofonijas autorus, kas uzticējušies un atkārtojuši minētās izdevuma korekcijas (lielākoties lingvistiski nepamatotas), piem., Megisers (sk. 3. nodalı), Dirê26, Pistoriuss ${ }^{27}$ utt.

\section{Latviešu tēvreize Megisera 16. gs. tēvreižu krājumos}

Kopā ar pasaules aprakstu uzplaukumu 16. gs. klajā nāca slavenie Vilhelma Postela, Teodora Bibliandera, Konrāda Gesnera un daudzu citu tēvreižu krājumi (Adelung 1806: 646-650). Tomēr latviešu lūgšana tajos

25 Turpat meklējama arī tēvreizes kopija.

26 Duret Claude 1613, Thresor de lhistoire des langves de cest vnivers. Contenant les Origines, Beautés, Perfections, Décadences, Mutations, Changemens, Conversions, \& Ruines des langues, Cologny: Matth. Berion.

27 Pistorius Georg Mauer 1621, Pater Noster, Oder Das Aller-heiligiste Gebett, Vater Unser: In Viertzig unterschiedlichen Sprachen zusammen colligiret, und inn Druck verfertiget, Ollmütz: Pauli Schramm. 
nebija atradusi vietu, lai gan dažos to varētu gaidīt, zinot, ka, piem., Gesners ${ }^{28}$ balstīīās uz Minstera 1550. g. kosmogrāfiju (Heinimann 2018: 167) un savā izdevumā minējis Livoniju un tajā runātās valodas. Vienīgais pašlaik zināmais atsevišķais 16. gs. tēvreižu krājums, kas satur latviešu tekstu, ir 1593. g. Hieronīma Megisera ${ }^{29}$ izdevums divās valodās: vācu Verdolmetschung Deß heyligen Vatter vnsers / in viertzig vnter-schiedlichen Sprachen .. un latīnu Specimen quadraginta diversarum atqve inter se differentium linguarum \& dialectorum ... ${ }^{30}$ Abi izdevumi nākuši klajā Frankfurtē Megisera sievas tēva Johana Špīsa (Johann Spiess) tipogrāfijā un, skatot latviešu tēvreizi, šksiet viena salikuma grāmatas. Tajās lūgšana atrodas tai pašā vietā, mainās tikai nosaukums, kas sniegts grāmatas valodā: vācu - 33. Lifflåndifch, bet latīņu - XXXIII. LIVONICE. Vācu izdevumā sniegtās latviešu tēvreizes fotokopiju iespiedis Staņislavs Kučinskis (1969) $)^{31}$ un vēlāk atkārtojis Antons Breidaks (1994), bet tekstu transkripcija atrodama Pjetro Umberto Dini (2010: 611) darbā $\bar{a}^{32}$ (sk. arī 7. un 8. tēvreizi pielikumā).

Krājumos sniegtā tēvreize nenāk no Minstera latīnu izdevuma, kā apgalvojis Kučinskis (1968: 33), bet acīmredzami tā ir Hāzentētera tēvreizes franciskais paveids, jo atkārtotas visas tiem tipiskās pazīmes - uzruna mus tabes, vārda salikumi eka kfchkan, pammart un iouna. Tiesa, kaut lūgšana nenāk tieši no Minstera izdevuma (sk. 4. nodą̧as shēmā), nav iespējams piekrist arī Breidaka (1994: 16) apgalvojumam, ka Megisera tēvreize jāuzskata par patstāvīgu 16. gs. variantu. Visticamāk, tās pazīmes radušās ar iepriekš minētās Tevē tēvreizes vai kāda līdzīga, pašlaik nezināma avota starpniecību. Atšksirībā no pēdējā MK franču izdevuma un citiem franču avotiem, Megisera un Tevē publicējumos sakrīt: parradvekẽ (MK - parraducken), ioune $(\mathrm{MK}-$ Iоииe) un aiz pett lietota interpunkcijas zīme, ko nepamato

${ }^{28}$ Conrad Gessner 1555, Mithridates De differentiis lingvarvm tvm vetervm tum quae hodie apud diuerfas nationes in toto orbe terrarũ in ufu funt, 60. lpp.

${ }^{29}$ Hieronymus Megiser (ap 1544-1618/1619) - daudzu grāmatu autors, tiek uzskatīts par polimātu (Doblinger 1905: 453), publicējis arī tēzauru, kurā atrodami daži vārdi latviešu valodā (sk. Kabelka 1939).

30 Otrais, pārveidots un papildināts laidiens vācu un latīṇu valodā izdots 1603. g., bet tā pārizdevums - 1616. g. (Carhart 2019: 268). Visos atrodama latviešu tēvreize, tomēr tā atškiras no 16. gs. izdevumā sniegtās.

31 Tiesa, Kučinskis (1969: 33-34) neidentificē divus izdevumus, jo, lai gan nosaukumu sniedz latīṇu valodā, fotokopijā redzamā tēvreize ir no izdevuma vācu valodā. Breidaka (1994) darbā tieši tāpat.

32 Pēc personīgas sarunas ar autoru noskaidrojās, ka, iespējams, Dini (2010: 611) sniegtā 1591. g. Megisera tēvreize patiesībā ir 1593. g. latīṇu izdevums, lai gan transkripcija nedaudz atškiras no oriğināla. 
valodas log̣ika, un tādējādi maz ticams, ka tā ir nejauša sakritîba. ${ }^{33}$ Taču vispār atsevišksu burtu rakstībā Megisera tēvreize atšksiras no Tevē, jo likumsakarīgi u u vietā atrodams vv: fchuuetitz - fchvvetitz, touus - tovvs, bet vu vietā vv: vuaartz - vvartz, vualstibe - vvalstibe, vurfan - vvrfan, vuuffe - vvuffe. Arī ecksckan - eckfckan, debbeßis - debbefsis, meß - mefs, fchodeen - fchodeẽ, mums - mũs, pammart - pãmart, iouna - jouna utt. (sk. 6. un 7. tēvreizi pielikumā). Tātad, lai cik tuvs šis variants būtu Tevē tēvreizei, tas atšksiras, taču nepietiekami, lai to sauktu par patstāvīgu 16. gs. tēvreizes variantu, - tas seko Hāzentētera tēvreizes franciskajam paveidam. ${ }^{34}$

Noslēgumā vēl daži vārdi jāsaka par it kā pastāvošo 1591. g. Megisera tēvreižu krājuma izdevumu. Kučinskis (1969: 33) savā rakstā par to izteicies loti nedroši - to pieminot Megisera biogrāfi (nevienu necitē), bet pats neesot redzējis un nevarot neko teikt. Breidaks (1994: 15) to jau piemin kā faktu pirmais Specimen esot iznācis 1591. g., tomēr latviešu valodniekiem tas neesot zināms. Bet Dini (2010: 611) darbā atrodama pat tā 1591. g. tēvreizes transkripcija. Dažos agrākajos ārzemju autoru darbos (Adelung 1806: 649; Hallam 1842: 406), kas vēlāk daudz citēti (Adiego 2016: 184), arī agrākajās apkopotajās biogrāfijās (Le-Long 1723: 46; Michaud 1821: 116) un katalogos (Hervás 1800: 41) atrodams 1592. g. kā Specimen izdošanas gads, turpretī minētais 1591. g. pārskatītajos avotos neparādās. ${ }^{35} \mathrm{Nedz} 1591$. g., nedz 1592. g. Megisera tēvreižu krājumu nemin un par pirmo viņa krājuma izdevumu uzskata tieši 1593. g. grāmatu Megisera dzīves gājuma pētnieks Maks Doblingers (Doblinger 1905: 477), arī tēvreižu krājuma faksimila autors Rūdolfs Trofeniks (Trofenik 1968), vēl Berčičs (1967), Budiša (1986), citi slovēņu pētnieki ${ }^{36}$. Tā kā izdevums neveiksmīgi meklēts arī dažādās Eiropas bibliotēkās, būtu jādomā, ka 1591. g. Megisera tēvreižu krājums neeksistēja, bet pārpratums radies saistībā ar to, ka 1593. g. bija izdoti divi viņa tēvreižu krājumi.

33 Pārējos avotos ne aiz, bet pirms pett ir komats, kols, slīpsvītra vai nav nekas, piem.: Lācijs 1557. g.: lovna badeckle, pett passarza

1561. g. MK vācu valodā: louna badeckle / pett paffarga

1568. g. MK franču valodā: Iouua badeckle pett paffarga

1575. g. MK franču valodā: Iouua badeckle : pett paffarga.

34 Vērts piezīmēt, ka Tevē tai pašā lappusē sniedz poḷu, zviedru, somu un latviešu tēvreizes, un, salīdzinot tās ar Megisera krājumā esošajām, var redzēt, ka poḷu tēvreize atšksiras, taču somu tēvreize ir līdzīga.

35 Tiesa, 1592. g. Megisers ir izdevis citas grāmatas - Dictionarium quatuor linguarum, Paroimiologias u. c.

36 Slovēṇu rakstu valodas pētnieki ir daudz rakstījuši par Megiseru, jo viņš tiek uzskatìts par pirmās slovēṇu daudzvalodu vārdnīcas, kā arī otrās gramatikas autoru (Ahačič 2007). 


\section{Hāzentētera tēvreizes atkalizmantošanas virzieni un pierakstu sakritība}

Apkopojot šai rakstā teikto ar Minstera izdevumu savstarpējiem sakariem (sk. Kazakènaitė 2020), iespiestās latviešu tēvreizes hipotētiskos ceḷus no viena avota uz otru iespējams attēlot arī sakaru shēmā. ${ }^{37}$ Tajā teksta atkalizmantošanas virzieni ir noteikti pēc kopīgajām korekcijām, kas lielākoties ir rakstībā. Jāuzsver, ka secinājumi izdarīti, balstoties uz 40 latviešu tēvreizes publicējumiem, un nav attiecināmi uz visu attiecīgā autora darbu, proti, tas nenozīmē, ka 1598. g. MK vācu izdevums no jauna tulkots, par pamatu ņemot 1575. g. MK franču izdevumu, utt.

Shēmā var redzēt, ka, neskaitot identos publicējumus, 16. gs. ārzemju grāmatās pastāvējuši vismaz 29 tēvreizes varianti. Protams, atšksirības starp tiem ir salīdzinoši sīkas, un skaidri redzams, ka tām visām pamatā - tieši vai ar citu avotu starpniecību - bijusi hipotētiskā Hāzentētera tēvreize.

\section{Apkopojums}

Rakstā pārskatīti astoņi 16. gs. ārzemju grāmatās atrodami latviešu tēvreizes publicējumi. Lai gan savstarpēji tie vairāk vai mazāk atšksiras, visiem pamatā bijusi Minstera kosmogrāfijā publicētā Hāzentētera tēvreize. Salīdzinot ar iespējamiem MK izdevumiem, visos pētītajos 16. gs. kosmogrāfiju publicējumos redzams tiešs sakars ar tiem, tomēr Megisera krājumos tēvreize, visticamāk, nonākusi ar Tevē vai kāda cita pašlaik nezināma darba starpniecību. Pēc analīzes var apstiprināt iepriekšējo autoru (Adelung 1806; Schirren 1859; Meringer 1895 u. c.) secinājumu, ka Lācijs izmantojis 1550. g. vai, mazāk ticams, idento 1553. g. vācu MK, un precizēt arī teikto par Belski (Meringer 1895; Chrzanowski 1926 utt.), ka viņa tēvreizes publicējumam pamatā bijis kāds 1550.-1561. g. vācu MK, varbūt 1558. g. vai identais 1561. g., izdevums. Tomēr acīmredzami Tevē nav izmantojis vācu vai latīṇu MK, kā lasāms piezīmē zem Sējas ziņojuma (1925: 285), bet MK francisko paveidu, šskiet, 1565. g. vai idento, tolaik jaunāko, 1568. g. izdevumu.

Nevienā grāmatā latviešu tēvreize nav precīzi norakstīta burts burtā no pirmavota - publicējumi atšksiras gan formāli, gan rakstības ziṇā. Visvairāk no visiem 16. gs. tēvreizes pierakstiem izceḷas M. Belska sniegtā, kura pielāgota poḷu tēvreizei, mainot ne vien vārdu secību (Bus praac tows), bet arī rakstību (nebess, wßey). Labākais piemērs, kas pierāda norakstītāju latviešu

37 Savā ziṇā shēmu var apvienot ar Dravinga (1965: 26) sniegto, kurā atspogulotas arī agrākas tēvreizes rokrakstā. 


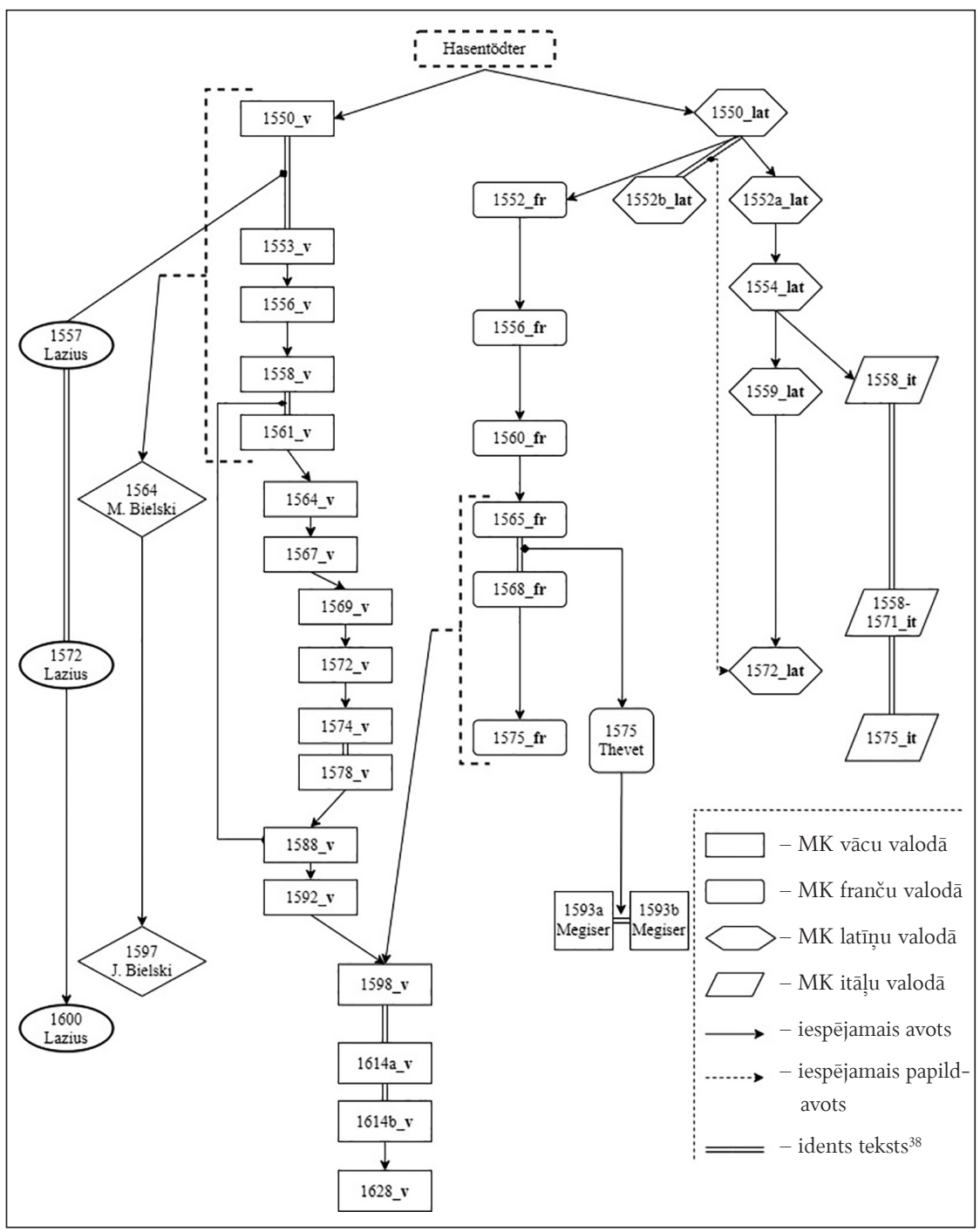

Shēma. Iespiestās latviešu tēvreizes hipotētiskie atkalizmantošanas virzieni

38 Vārds idents attiecināms uz latvisko tekstu, bet ne teksta salikumu, t. i., vārdu pārnešana citā rindā var atškirirties — kā Lācija pirmajos divos izdevumos. 
valodas neprasmi, ir nepamate mums greche mufche/ ka meff nepamat muffe paraduekien, kur noliegto formu vēl Meringers skaidrojis ar poḷ valodas ietekmi. Arī pārējo publicējumu autori nav pratuši valodu, kas sekmēja lielo tās pašas tēvreizes variantu skaitu — no šobrīd zināmiem 40 latviešu tēvreizes 16. gs. publicējumiem ārzemju grāmatās (ieskaitot šajā rakstā pētītos un visus MK esošos) 29 savstarpēji atšksiras, tātad tikai 11 ir identi kādam citam (sk. iepriekš shēmā).

\section{Avoti}

Bielski, Marcin 1564.

Bielski, Marcin [Joachim Bielski] 1597.

Lazius, Wolfgang 1557.

Lazius, Wolfgang 1572.

Lazius, Wolfgang 1600.

Megiserus, Hieronymus 1593a.

Megiserus, Hieronymus 1593b.
Kronika. tho iesth, Historya Swiata na sześc wiekow, a cżterzy Monarchie [..]. Kraków: Mateusz Siebeneycher. Nacionālā Osoliņska institūta eks. [sign. XVI.F.4111]. Digitālā versija: Dolnośląska Biblioteka Cyfrowa; 438. lpp.

Kronika polska, Marcina Bielskiego nowo przez Ioach. Bielskiego syná iego wydána, W Krakowie: w drukarni Jakuba Siebeneychera. Jagelonu Universitātes bibliotēkas eks. [sign. BJ St. Dr. Cim. 8691]. Digitālā versija: polona.pl; 605. lpp.

De gentivm aliquot migrationibus, sedibus fixis, reliquijs, linguarumq; initijs \& immutationibus ac dialectis, Libri XII [..]. Basileae: Ioannem Oporinum. VD16 L 849. Gentes Universitātes bibliotēkas eks. [sign. BIB.HISt.004964], Bavārijas Valsts bibliotēkas eks. [sign. ESlg/2 H.int. 67], Austrijas Nacionālās bibliotēkas eks. [sign. BE.6.G.33]. Digitālā versija: Münchener Digitalisierungszentrum; 787.-788. lpp.

De aliquot gentivm migrationibvs, sedibus fixis, reliquiis, linguarumq; initiis \& immutationibus ac dialectis, Libri XII [..]. Basileae: Officina Oporiniana. VD16 L 850. Bavāijas Valsts bibliotēkas eks. [sign. Res/2 H.int. 68]. Digitālā versija: Münchener Digitalisierungszentrum; 787.-788. lpp.

De gentivm aliqvot migrationibvs, sedibvs fixis, reliqviis, linguarumque initiis \& immutationibus ac dialectis, Libri XII. [..]. Francofvrti: Andreae Wecheli heredes, Claudium Marnium \& Ioannem Aubrium. VD16 L 851. Bavārijas Valsts bibliotēkas eks. [sign. 2 H.int. 69], Austrijas Nacionālās bibliotēkas eks. [sign. 207412D]. Digitālā versija: Münchener Digitalisierungszentrum; 628. lpp.

Verdolmetschung Deß heyligen Vatter vnsers / in viertzig vnterschiedlichen Sprachen / zusam-men gebracht / vnd zu einer Prob eines gróssern in solchen Sprachen furste-henden Wercks / in Truck verfertiget. Frankfurt am Mayn: Johann Spieß. Bernes Universitātes Minstergases bibliotēkas eks. [sign. MUE Bong V 41 : 3].

Specimen quadraginta diversarum atqve inter se differentium linguarum \& dialectorum; videlicet, Oratio Dominica, totidem linguis expressa. Frankcoforti: Iohannis Spiessij. Augsburgas pilsētas bibliotēkas eks. [sign. Spw 1445]. Digitālā versija: Münchener Digitalisierungszentrum. 
Thevet, André 1575.
La Cosmographie Vniverselle d'Andre Thevet Cosmographe dv Roy [..], Tome Second. A Paris: Chez Guillaume Chandiere. Francijas Nacionālās bibliotēkas eks. [sign. FOL-SG BON B-2]. Digitālā versija: Gallica katalogā; 882. lpp.

\section{Literatūra}

Adelung, Johann Christoph. 1806.

Adiego, Ignasi-Xavier. 2016. Romani or Pseudo-Romani? On the Lord's Prayer in 'Nubian' by Jean-Baptiste Gramaye (1622). Romani Studies 26 (2), 175-186.

Ahačič, Kozma. 2007.

Arbuzovs, Leonids. 1920.

Augstkalns, Alvils. 1930.

Barycz, Henryk. 1936.

Berčič, Branko. 1967.

Bezzenberger, Adalbert. 1875 .

Biezais, Haralds. 1955.

Biezais, Haralds. 1957.

Breidaks, Antons. 1994.

Brežgo, B. 1939.

Budiša, Dražen. 1986.

Carhart, Michael C. 2019.

Chrzanowski, Ignacy. 1926.

da Silveira Cardozo,

Manoel. 1944.

Dini, Pietro Umberto. 2010.
Primeri nekaj sklanjatev in spregatev v Megiserjevem Dictionarium quatuor linguarum 1592: druga slovnica slovenskega jezika. Jezikoslouni Zapiski 13 (1-2), 23-32.

Latveešu tēvreize senos tekstos. Izglītības Ministrijas Mēnešraksts 10, 357-362.

Par vecajām tēvreizēm. Izglìtības Ministrijas Mēnešraksts 1, 309-311.

Bielski Joachim. In Polski Stownik Biograficzny. T. 2: Beyzym Jan - Brownsford Marja. Kraków: Polska Akademia Umiejętności, 61-64.

V letu 1593 natisnjeni slovenski očenaš. Knjižnica 11 (1/4). Zveza bibliotekarskih društev Slovenije, 125-128.

Litauische und lettische Drucke des 16. Jahrhunderts. Göttingen: Robert Peppmüller.

Ein neugefundener Text des lettischen Vaterunsers aus dem 16. Jahrhundert. Nordisk Tidskrift för bok- och biblioteksväsen 42, 47-54.

Der älteste Text des lettischen Vaterunsers. Nordisk Tidskrift för bok- och biblioteksväsen 44, 1-10.

H. Megisers un veclatviešu rakstu valodas sākotne. Baltu filoloğija 4, 15-18.

Kā XVI g. s. vēsturnieki B. Vapovskis un M. Beḷskis apraksta Latviju un latviešus. Sējējs 10, 1020-1025.

Južnoslavenski tekstovi u Megiserovu djelu »Prob einer Verdolmetschung in fünfftzig underschiedlichen Sprachen «... iz 1603. Croatica 17 (24-25), 6-76.

Leibniz Discovers Asia: Social Networking in the Republic of Letters. JHU Press.

Marcin Bielski. Studjum historyczno-literackie. Lwów-Warszawa: Książnica-Atlas.

Some Remarks concerning André Thevet. The Americas 1 (1), 15-36.

ALILETOESCVR: linguistica baltica delle origini. Teorie e contesti linguistici nel Cinquecento. Livorno: Books\&Company. 
Doblinger, Max. 1905.

Döring, J. 1883.

Draviņš, Kārlis. 1955.

Draviņš, Kārlis. 1965.

Hallam, Henry. 1842.

Heinimann, Siegfried. 2018.

Hervás, Lorenzo. 1800.

Hinze, Friedhelm. 1976.

Jurkiewicz, Jan. 2009.

Kabelka, Jonas. 1939.

Kazakėnaite, Ernesta. 2020.

Kössinger, Norbert. 2015.

Kratochwill, Max. 1965. Wolfgang Lazius. Wiener Geschichtsblätter 20 (3), 449-452.

Kučinskis, Staņislavs. 1969.

Lautenbahs, Jēkabs. 1928.

Le-Long, Jacques. 1723.

Mayr, Michael. 1894.

Meringer, Rudolf. 1895.

Michaud, Louis Gabriel (red.). 1821.

Ozols, Arturs. 1965.

Prande, Alberts. 1926.

Pokrotniece, Kornēlija. 2012.
Hieronymus Megisers Leben und Werke. Mitteilungen des Instituts für Österreichische Geschichtsforschung 26, Innsbruck, 431-478.

Über das augebliche Vaterunser der Heruler, nach Schirren; Vortrag von Dr. K. Bluhm. Sitzungs-Berichte der kurländischen Gesellschaft für Literatur und Kunst nebst Veröffentlichungen des kurländischen Provinzial-Museums, aus dem Jahre 1882. Mitau: J. F. Steffenhagen und Sohn, 5-11.

Bruno tēvreizes avoti. Cela Zìmes 28, 473-476.

Altlettische Schriften und Verfasser 1. Lund: Slaviska institutionen vid Lunds universitet.

Introduction to the Literature of Europe in the Fifteenth, Sixteenth, and Seventeenth Centuries 1. New York: Harper \& brother.

Oratio Dominica Romanice: Das Vaterunser in den romanischen Sprachen von den Anfängen bis ins 16. Jahrhundert mit den griechischen und lateinischen Vorlagen. Walter de Gruyter.

Catálogo de las lenguas de las naciones conocidas: Lenguas y naciones americanas 1. Madrid: Ranz.

Hat Matthãus Prätorius (um 1635-1707) ein „Kurisches“ Vaterunser gekannt?. Acta Baltico-Slavica 10, 235-264.

Albertas Vijūkas-Kojelavičius - heruliškos lietuvių kilmės teorijos pradininkas. Lituanistica 3/4, 105-115.

Latviški žodžiai 1603 metų Thesaure Polyglotte. Archivum Philologicum 8, 19-21.

kosmogrāfijas izdevumos. Baltu filologíija 29 (2), 55-87.

Frühe Formen der Auseinandersetzung mit deutschsprachiger Literatur des Mittelalters in Wien. Die Beispiele Hugo Blotius und Wolfgang Lazius. Jahrbuch für Internationale Germanistik 2, 25-43.

Latviešu valodas apliecinātājs Hieronims Megisers. Gaisma 4, 33-35.

Prof. Dr. J. Lautenbaha Latviešu literatūras vēsture II. Rīga: Zemneeka domas.

Bibliotheca sacra in binos syllabos distincta, quorum prior qui iam tertio auctior prodit 2. Paris: Montalant.

Wolfgang Lazius als Geschichtsschreiber Österreichs: ein Beitrag zur Historiographie des 16. Jahrhunderts; mit Nachträgen zur Biographie. Innsbruck: Wagner.

Ein altes lettisches Vaterunser. Archiv für slavische Philologie 17, Berlin: Weidmannsche Buchhandlung.

Biographie universelle, ancienne et moderne, ou histoire, par ordre alphabétique [..] 28, Paris.

Veclatviešu rakstu valoda. Rīga: Liesma.

Latvju rakstniecība portrejās. Rīga: LETA.

Grēki un parādi - pamest vai piedot? (Ieskats latviešu senajās tēvreizēs). Baltistica VIII priedas, 111-122. 
Schirren, Carl. 1858.

Schirren, Carl. 1859.

Schlesinger, Roger, Arthur Stabler. 1986.

Sēja, Pēteris. 1925.

Svatek, Petra. 2006.

Trofenik, Rudolf. 1968.

Turowski, Kazimierz Józef. 1856.

VD16 =

Zēvers, Jānis. 1929.
Das Vaterunser des Heruler, als Plagiat erwiesen. Bulletin histórico-philologi de l' Acad. Im. 16, Melanges russes 3, 659-674. Das Vaterunser des Heruler, als Plagiat erwiesen. Bulletin de la Classe Historico-Philologique de l' Académie Impériale des Sciences de St.-Pétersbourg 16, 131-141.

André Thevet's North America: A Sixteenth-Century View. Kingston, Montreal: McGill-Queen's Press.

Vēl kāds latviešu tēvreizes teksts. Izglìtỉbas Ministrijas Mēnešraksts 11, 285. lpp.

Wolfgang Lazius. Leben und Werke eines Wiener Gelehrten des 16. Jahrhunderts. Wiener Geschichtsblätter 61 (1), 1-22.

Das Vaterunser: in vierzig Sprachen: Frankfurt 1593 / Hieronymus Megiser (= Litterae Slovenicae 4). München.

Kronika polska Marcina Bielskiego, T. 2, Księga 4, 5. Sanok: K. Pollak.

Das Verzeichnis der im deutschen Sprachbereich erschienenen Drucke des 16. Jahrhunderts. Izmantota elektroniskā versija: http://www.vd16.de

Vecas tēvreizes latviešu valodā. Izglìtības Ministrijas Mēnešraksts $12,512-518$.

Ernesta Kazakènaite

Baltistikos katedra

Baltijos kalbu ir kultūrų institutas

Filologijos fakultetas

Vilniaus universitetas

Universiteto g. 5, LT-01131, Vilnius, Lietuva

ernesta.kazakenaite@flf.vu.lt 
Pielikums. Astoņu pasaules aprakstos un tēvreižu krājumos iespiestu 16. gs. latviešu tēvreižu paralēlais korpuss (iespējams apvienot ar MK korpusu (sk. Kazakėnaitė 2020: 80-86)).

\begin{tabular}{|c|c|c|c|c|c|c|c|c|c|}
\hline \multirow[b]{2}{*}{ Nr. } & \multirow[b]{2}{*}{ Datums } & \multirow[b]{2}{*}{ Avots } & \multicolumn{7}{|c|}{ Vārdi } \\
\hline & & & $1:$ & 2 & 3 & 4 & 5 & 6 & 7 \\
\hline 1 & 1557 & Lazius & TABES & MVS & KAS & TV & ES & ECKSCHAN & DEBBESSIS \\
\hline 2 & 1572 & Lazius & TABES & MVS & KAS & TV & ES & ECKSCHAN & DEBBESSIS \\
\hline 3 & 1600 & Lazius & TABES & MVS & KAS & $\mathrm{TV}$ & $\mathrm{ES}$ & ECKSCHAN & DEBBESSIS \\
\hline 4 & 1564 & Bielski & Tabes & mus & kaff & tu & es & ekfcan & nebeffis \\
\hline 5 & 1597 & Bielski & TAbes & mus & kas & tu & es & ekfcan & nebefsis/|| \\
\hline 6 & 1575 & Thevet & MVs & tabes & kas & tu & es, & ecksckan & debbeßis, \\
\hline 7 & $1593 a$ & Megiser & Mus & tabes, & kas & tu & es & eck-||lckan & debbefsis : \\
\hline 8 & $1593 b$ & Megiser & Mus & tabes, & kas & tu & es & eck- || fckan & debbefsis: \\
\hline
\end{tabular}

\begin{tabular}{|c|c|c|c|c|c|c|c|c|c|c|}
\hline \multirow[b]{2}{*}{$\mathrm{Nr}$. } & \multirow[b]{2}{*}{ Datums } & \multirow[b]{2}{*}{ Avots } & \multicolumn{8}{|c|}{ Vārdi } \\
\hline & & & 15 & 16 & 17 & 18 & 19 & 20 & 21 & $21 \mathrm{a}$ \\
\hline 1 & 1557 & Lazius & TOVVS & PRAATZ & \multicolumn{2}{|c|}{ BVSKA } & ECKSCHAN & DEBBES & $\mathrm{TA}$ & \\
\hline 2 & 1572 & Lazius & TOVVS & PRAATZ & \multicolumn{2}{|c|}{ BVSKA|! } & ECKSCHAN & DEBBES & $\mathrm{TA}$ & \\
\hline 3 & 1600 & Lazius & TOVVS & PRAATS & \multicolumn{2}{|c|}{ BVSKA |! } & ECKSCHAN & DEBBES & $\mathrm{TA}$ & \\
\hline 4 & 1564 & Bielski & bus & praatz & tows & $\mathrm{ka}$ & ekfcan & nebeff & ta & \\
\hline 5 & 1597 & Bielski & Bus & praac & tows/ & $\mathrm{ka}$ & ekfcan & nebes & tall & \\
\hline 6 & 1575 & Thevet & touus & praatz & bus & eka & kschkan & debbes & ta & \\
\hline 7 & $1593 a$ & Megiser & tovvs & praatz & bus & eka & kschkan & debbes & ta & \\
\hline 8 & $1593 b$ & Megiser & tovvs & praatz & bus & eka & kschkan & debbes & ta & \\
\hline
\end{tabular}

\begin{tabular}{|c|c|c|c|c|c|c|c|c|c|}
\hline \multirow[b]{2}{*}{$\mathrm{Nr}$. } & \multirow[b]{2}{*}{ Datums } & \multirow[b]{2}{*}{ Avots } & \multicolumn{7}{|c|}{ Vārdi } \\
\hline & & & $29 a$ & 30 & 31 & 32 & 33 & 34 & 35 \\
\hline 1 & 1557 & Lazius & & PAMMATE & MVMS & MVSSE & GRAKE & $\mathrm{KA}$ & MESS \\
\hline 2 & 1572 & Lazius & & PAMMATE & MVMS & MVSSE & GRAKE & $\mathrm{KA}$ & MESS \\
\hline 3 & 1600 & Lazius & & PAMMATEMVNS & & MVSSE & GRAKE & $\mathrm{KA}$ & MESS \\
\hline 4 & 1564 & Bielski & & nepamate & mums & greche & mufche/|| & $\mathrm{ka}$ & meff \\
\hline 5 & 1597 & Bielski & & Nepámate & mums & greche & mufche/ & $\mathrm{ka} \mid \mathrm{l}$ & mes \\
\hline 6 & 1575 & Thevet & & pammate & mums & muffe & grake & $\mathrm{ka}$ & meß \\
\hline 7 & $1593 a$ & Megiser & & pammate & mũs | & muffe & grake, & $\mathrm{ka}$ & mefs \\
\hline 8 & $1593 \mathrm{~b}$ & Megiser & & pammate & mũs|| & muffe & grake, & $\mathrm{ka}$ & mefs \\
\hline
\end{tabular}


Paskaidrojumi (zīmes nepieder tēvreizes tekstam)

|| - rindas beigas grāmatā;

* - nav skaidrs, iespējams lasīt arī citādāk;

- šādi iekrāsoti lauciṇi rāda atškiriību no pirmā attiecīgā darba publicējuma.

\begin{tabular}{|c|c|c|c|c|c|c|c|c|}
\hline \multirow[b]{2}{*}{$\mathrm{Nr}$} & \multicolumn{8}{|c|}{ Vārdi } \\
\hline & 8 & $8 \mathrm{a}$ & 9 & 10 & 11 & 12 & 13 & 14 \\
\hline 1 & SCHVVE- $\mid$ | TITZ & & TOVVS & VVAARCZ & ENAK & MVMS & TOVvs & VVALSTIBE \\
\hline 2 & SCHVVETITZ & & Tovvs | & VVAARCZ & ENAK & MVMS & TOVVS & VVALSTIBE \\
\hline 3 & SCHVVETITZ & & Tovvs | I & VVAARTCZ & ENAK & MVMS & TOVVS & VVALSTIBE \\
\hline & & & & & & & & \\
\hline 4 & Suetzit3|| & & tuoff & vaart3/ & enat & mums & Valstibe & tows \\
\hline 5 & fwecic & & twoff & waarc. & Enat & mums & valstibe & tows. \\
\hline 6 & fchuuetitz & & tous & vuaartz, & Enack & mums & touus |. & vualstibe, \\
\hline & & & & & & & & \\
\hline 7 & fchvve- $\mid$ |titz & & tous & vvartz: & enack $\mid$ & mums & tovvs & vvalstibe : \\
\hline 8 & fchvve- || titz & & tous & vvartz: & enack $\mid$ & mums & tovvs & vvalstibe : \\
\hline
\end{tabular}

\begin{tabular}{|c|c|c|c|c|c|c|c|c|}
\hline \multirow[b]{2}{*}{ Nr. } & \multicolumn{8}{|c|}{ Vārdi } \\
\hline & 22 & 23 & 24 & 25 & 26 & 27 & 28 & 29 \\
\hline 1 & VVVRSAN || & SVMMES & MVSSE & DENISCHE & MAYSE & DVTH & MVMS & SCHODEN $\mid$ \\
\hline 2 & VVVRSAN & SVMMES & MVSSE & DENISCHE & MAY- $\mid$ SE & DVTH & MVMS & SCHODEN \\
\hline 3 & VVVRSAN & SVMMES & MVSSE & DENISCHE & MAYSE | | & DVTH & MVMS & SCHODEN \\
\hline 4 & & Semes/ & mnffe* || & deniße & mayße & dut & mums & fchoden \\
\hline 5 & & femes. & Mufse & demfe & mayfe & dut & mums & fchoden \\
\hline 6 & vurfan & femmes, & Muffe & denifche & maife l. & duth & mums & fchodeen, \\
\hline 7 & vvr-||fan & femmes: & muffe & deni-||fche & maife & duth & mums || & fchodeẽ: \\
\hline 8 & vvr-||fan & femmes: & muffe & deni-||fche & maife & duth & mums || & fchodeẽ: \\
\hline
\end{tabular}

\begin{tabular}{|c|c|c|c|c|c|c|c|c|c|}
\hline \multirow[b]{2}{*}{$\mathrm{Nr}$. } & \multicolumn{9}{|c|}{ Vārdi } \\
\hline & 36 & 37 & 38 & 39 & 40 & 41 & 42 & 43 & 44 \\
\hline 1 & PAMMAT & MVS- || SE & PATRA DVEKEN, & $\mathrm{NE}$ & VVEDDE & MVMS & LOVNA & BADE- I | CKLE, & PETT \\
\hline 2 & PAMMAT & MVSSE & PATRA DVEKEN, & $\mathrm{NE}$ & VVEDDE & MVMS & LOVNA & BA- | DECKLE, & PETT \\
\hline 3 & PAMMAT & MVSSE & PATRA DVEKEN, & $\mathrm{NE}$ & VVEDDE & MVMS & LOVNA & BADE- | | CKLE, & PETT \\
\hline 4 & ¿nepamat & muffe & paraduekien & & $1 e$ & & eluna & badekle & \\
\hline 5 & nepamat & mulsepara & duekien. & $\mathrm{Ne}$ & vede & mums & veluna & badekle. & Pet \\
\hline 6 & pammart & muffe & parradueken. & $\mathrm{Ne} \|$ & euuedde & mums & iouna & badeckle & pett, \\
\hline 7 & pã- || mart & muffe & parradvekẽ: & ne & euuedde & mũs & : jouna & badeckle & pett : \\
\hline 8 & pã-||mart & muffe & parradvekẽ: & ne & euuedde & mũs & jouna|| & badeckle & pett : \\
\hline
\end{tabular}




\begin{tabular}{|c|c|c|c|c|c|c|c|c|c|}
\hline \multirow[b]{2}{*}{ Nr. } & \multirow[b]{2}{*}{ Datums } & \multirow[b]{2}{*}{ Avots } & \multicolumn{7}{|c|}{ Vārdi } \\
\hline & & & 45 & 46 & 47 & 48 & 49 & $49 a$ & 50 \\
\hline 1 & 1557 & Lazius & PASSARZA & MVMS & $\mathrm{NV}$ & VVVSSE & LOVNE, & & Amen. \\
\hline 2 & 1572 & Lazius & PASSARZA & MVMS & $\mathrm{NV}$ & VVVSSE & LOVNE, & & Amen. \\
\hline 3 & 1600 & Lazius & PASSARZA & MVMS & $\mathrm{NV}$ & VVVSSE & LOVNE, & & Amen. \\
\hline 4 & 1564 & Bielski & paffarga & mums & nu & wßey & leune. & & \\
\hline 5 & 1597 & Bielski & pafsarga & mums || & na & wfei & lewne. & & \\
\hline 6 & 1575 & Thevet & paffarga & mums & nu & vuuffe & ioune. & & Amen. \\
\hline 7 & $1593 a$ & Megiser & paffarga & mums & nu & vvuffe & ioune.|| & & Amen. \\
\hline 8 & $1593 \mathrm{~b}$ & Megiser & paffarga & mums & nu & vvuffe & ioune.|| & & Amen. \\
\hline
\end{tabular}

\title{
SUMMARY
}

\section{Nepamet mums grēkus mūsu ('Don't forgive us our trespasses') or The Lord's Prayer in Latvian in $16^{\text {th }}$ Century Cosmographies and Collections of the Lord's Prayer}

\author{
Ernesta KAZAKĖNAITÉ
}

The article focuses on The Lord's Prayer in Latvian published in $16^{\text {th }}$ century Cosmographies and Collections of the Lord's Prayer. In some sense, this study is a continuation of my previous research about Johann Hasentödter's prayer in the Cosmography of Sebastian Münster (see Kazakènaitė 2020). Although all writers - Wolfgang Lazius, Marcin and Joachim Bielski, André Thevet and Hieronymus Megiser - are known to Old Latvian writings researchers, there are some more details that are specified in this article.

First of all, despite the confusion in the literature about the Collection of the Lord's Prayer by Megiser, it should be stated that his first collection was published in 1593, not 1591 or 1592. The German and Latin editions of this collection were published simultaneously in that year. Both contain the Latvian prayer.

Secondly, though all the publications contain relatively different versions of the Latvian prayer, they all had the same primary source - Hasentödter's prayer. All the cosmographies that were analyzed in this article had a direct connection to some of the Cosmography of Sebastian Münster (further - MC) editions. For example, Lazius took the prayer from the 1550 or identical 1553 MC German edition; Bielski used one of the 1550-1561 German editions of the MC (perhaps the 1558 or identical 1561 edition); but Thevet's publication most likely consulted the 1565 or identical 1568 French edition of the MC. Only one of the analyzed sources had no direct connection to the MC, namely, Megiser seemingly took his prayer from Thevet's Cosmography.

Thirdly, in none of these books is the Latvian prayer identical to the primary source it differs both formally and in writing. The most different of all the Latvian versions of The Lord's Prayer published in the $16^{\text {th }}$ century can be found in the book Kronika. tho iesth, Historya Swiátá na ßeść wiekow (1564) by Marcin Bielski, republished later in 1597, with some changes by his son Joachim Bielski. What is notable, is that the main text of The Lord's Prayer is in 
Polish while the Latvian translation is in a smaller font under the relevant Polish words. It is obvious that neither Bielski nor the other cosmographers who published The Lord's Prayer in Latvian knew this language. It is well illustrated by the following example from Bielski's book - nepamate mums greche mufche / ka meff nepamat muffe paraduekien 'don't forgive us our trespasses, as we don't forgive those who trespass against us' - where instead of 'forgive' Bielski used 'don't forgive'. The lack of Latvian language understanding contributed to a large number of the variants of one particular text. Out of the 40 currently known publications that have their root in Hasentödter's prayer, at least 29 variants could be counted in the first fifty years after it appeared, although some of them differ slightly, e. g. only in orthography. 